F. Reprod. Fert. (1966) 11, 281-282

BRIEF COMMUNICATION

\title{
ORIGIN OF TRANSAMINASE IN HUMAN SEMEN
}

\author{
R. ELIASSON \\ Department of Physiology, Faculty of Medicine, Karolinska Institutet, Stockholm, Sweden
}

(Received 9th June 1965, revised 21st October 1965)

\begin{abstract}
Summary. Human seminal plasma contains highly active glutamic oxaloacetic transaminase (aspartate aminotransferase). Using the splitejaculation method it has been demonstrated that the enzyme is largely concentrated in the first portion of the ejaculate, indicating that it is derived from the prostate gland.
\end{abstract}

The occurrence of glutamic oxaloacetic transaminase (GOT) (aspartate aminotransferase) in human semen has been demonstrated by Pavoa \& Villela (1960), Gregoire, Rakoff \& Ward (1961) and Searcy, Craig \& Bergquist (1962), the activity being about 10 to 20 times higher than in blood plasma. There appeared to be a correlation between enzyme activity and sperm density, but high activity has also been encountered in semen samples which were without spermatozoa.

In order to study the origin of seminal GOT, samples of human semen were collected from eight healthy young men according to the method described by Lundquist (1949) and Eliasson (1959, 1964). Each fraction was analysed for acid phosphatase (which is contributed by the prostate gland), fructose (which is derived from the seminal vesicles) and the transaminase. Sperm density was determined in samples from three of the eight volunteers. Acid phosphatase was determined according to Lundquist (1949), fructose according to Karvonen \& Malm (1955) and GOT according to Reitman \& Frankel (1957). Some modifications were used as described by Eliasson (1965).

The distribution of fructose, acid phosphatase, GOT and spermatozoa in the semen of the three subjects is given in Table 1. In these experiments, as well as in the five others, the general pattern of distribution for acid phosphatase and GOT was similar, i.e. the highest activity being present in the first fraction. This indicated that GOT is secreted from the prostate. The distribution pattern did not indicate that the secretion from the seminal vesicles contained any significant activity. It could not be excluded that part of the enzyme activity in some of the fractions was due to a leakage of GOT from the spermatozoa, since these also contain transaminase, but gel-electrophoretic studies indicate that the transaminase activity of spermatozoa is mainly due to an iso-enzyme which is different from that of seminal plasma (Eliasson, unpublished observations). 
TABLE I

DISTRIBUTION OF AGID PHOSPHATASE, GLUTAMIC OXALOACETIC TRANSAMINASE (GOT), FRUCTOSE AND SPERMATOZOA IN FRACTIONS 1 TO 4 OF HUMAN EJAGULATES FROM THREE SUBJECTS A, B AND C

\begin{tabular}{r|c|c|c|c|c}
\hline $\begin{array}{c}\text { Fraction } \\
\text { No. }\end{array}$ & $\begin{array}{c}\text { Fresh } \\
\text { weight } \\
(\mathrm{g})\end{array}$ & $\begin{array}{c}\text { Acid } \\
\text { phosphatase } \\
(\text { units } / \mathrm{ml})\end{array}$ & $\begin{array}{c}\mathrm{GOT} \\
(\text { units } / \mathrm{ml})\end{array}$ & $\begin{array}{c}\text { Fructose } \\
(\mathrm{mg} / 100 \mathrm{ml})\end{array}$ & $\begin{array}{c}\text { Sperm } \\
\text { concentration } \\
\left(\times 10^{6} / \mathrm{ml}\right)\end{array}$ \\
\hline $\mathrm{A} 1$ & $0 \cdot 14$ & 15120 & 270 & $7 \cdot 5$ & $1 \cdot 5$ \\
2 & $0 \cdot 64$ & 2300 & 165 & 228 & 112 \\
3 & $1 \cdot 14$ & 1470 & 165 & 384 & $75 \cdot 4$ \\
4 & $0 \cdot 79$ & 830 & 90 & 480 & 20 \\
$\mathrm{~B} 1$ & $0 \cdot 08$ & 17040 & 720 & 50 & 41 \\
2 & $0 \cdot 28$ & 8160 & 640 & 110 & 34 \\
3 & $0 \cdot 88$ & 4720 & 270 & 300 & 10 \\
4 & $0 \cdot 86$ & 2880 & 80 & 470 & 0 \\
5 & 1.49 & 1520 & 70 & 590 & 0 \\
$\mathrm{C} 1$ & $0 \cdot 32$ & 5280 & 430 & 85 & 234 \\
2 & 1.30 & 3520 & 235 & 170 & 38 \\
3 & $0 \cdot 24$ & 2400 & 210 & 210 & 33 \\
4 & $0 \cdot 60$ & 3840 & 145 & 240 & 12 \\
5 & 0.75 & 3360 & 175 & 250 & 40 \\
\hline
\end{tabular}

This work is part of a project supported by the Swedish Medical Research Council (Y 616) and the Population Council (M 64.72; M 65.63). The skilful technical assistance of Miss B. Magnusson and Mrs B. Luttropp is thankfully acknowledged.

\section{REFERENCES}

Ellasson, R. (1959) Studies on prostaglandin. Acta physiol. scand. 46, Suppl. 158.

Eliasson, R. (1964) Origin of neuraminic acid in human seminal fluid. Nature, Lond. 203, 980.

Eliasson, R. (1965) Effect of frequent ejaculations on the composition of the human seminal plasma. F. Reprod. Fert. 9, 331 .

GREGOIRE, A. T., RAKOFF, A. E. \& WARD, K. (1961) Glutamic-oxaloacetic transaminase in semen of human, bull, and rabbit seminal plasma. Int. F. Fert. 6, 73.

Karvonen, M. J. \& MaLm, M. (1955) Colorimetric determination of fructose with indol. Scand. 7. clin. Lab. Invest. 7, 305.

LundQuist, F. (1949) Aspects of the biochemistry of human semen. Acta physiol. scand. 19, Suppl. 66.

Pavoa, H., JR \& Villela, G. G. (1960) Transaminase in seminal plasma of man. Experientia, 16, 199.

RetTman, S. \& Frankel, S. (1957) Colorimetric method for the determination of serum transaminase activity. Am. F. clin. Path. 28, 56.

Searcy, R. L., Graig, R. G. \& Bergquist, L. M. (1962) Levels of transaminases in human seminal plasma. Lancet, i, 1413. 